\title{
A global ozone profile climatology for satellite retrieval algorithms based on Aura MLS measurements and the MERRA-2 GMI simulation
}

\author{
Jerald R. Ziemke ${ }^{1,2}$, Gordon J. Labow ${ }^{3}$, Natalya A. Kramarova ${ }^{1}$, Richard D. McPeters ${ }^{1}$, Pawan K. Bhartia ${ }^{1}$, \\ Luke D. Oman ${ }^{1}$, Stacey M. Frith ${ }^{3}$, and David P. Haffner ${ }^{3}$ \\ ${ }^{1}$ NASA Goddard Space Flight Center, Greenbelt, Maryland, USA \\ ${ }^{2}$ Goddard Earth Sciences Technology and Research (GESTAR) and Morgan State University, Baltimore, Maryland, USA \\ ${ }^{3}$ SSAI, Lanham, Maryland, USA
}

Correspondence: Jerald R. Ziemke (jerald.r.ziemke@nasa.gov)

Received: 29 May 2021 - Discussion started: 22 June 2021

Revised: 19 August 2021 - Accepted: 31 August 2021 - Published: 5 October 2021

\begin{abstract}
A new atmospheric ozone profile climatology has been constructed by combining daytime ozone profiles from the Aura Microwave Limb Sounder (MLS) and Modern-Era Retrospective Analysis for Research Applications version 2 (MERRA-2) Global Modeling Initiative (GMI) model simulation (M2GMI). The MLS and M2GMI ozone profiles are merged between 13 and $17 \mathrm{~km}(\sim 159$ and $88 \mathrm{hPa})$, with MLS used for stratospheric and GMI for primarily tropospheric levels. The time record for profiles from MLS and GMI is August 2004-December 2016. The derived seasonal climatology consists of monthly zonal-mean ozone profiles in $5^{\circ}$ latitude bands from $90^{\circ} \mathrm{S}$ to $90^{\circ} \mathrm{N}$ covering altitudes (in $Z^{*} \log$-pressure altitude) from zero to $80 \mathrm{~km}$ in $1 \mathrm{~km}$ increments. This climatology can be used as a priori information in satellite ozone retrievals, in atmospheric radiative transfer studies, and as a baseline to compare with other measured or model-simulated ozone. The MLS/GMI seasonal climatology shows a number of improvements compared with previous ozone profile climatologies based on MLS and ozonesonde measurements. These improvements are attributed mostly to continuous daily global coverage of GMI tropospheric ozone compared with sparse regional measurements from sondes. In addition to the seasonal climatology, we also derive an additive climatology to account for interannual variability in stratospheric zonal-mean ozone profiles which is based on a rotated empirical orthogonal function (REOF) analysis of Aura MLS ozone profiles. This REOF climatology starts in 1970 and captures most of the in-
\end{abstract}

terannual variability in global stratospheric ozone including quasi-biennial oscillation (QBO) signatures.

\section{Introduction}

McPeters and Labow (2012) (hereafter, ML) and Labow et al. (2015) combined ozone profile data from ozonesondes and the Aura Microwave Limb Sounder (MLS) (Livesey et al., 2011) to use as climatological a priori information for satellite retrievals of ozone. These ozone profile climatologies were constructed by merging ozonesondes in the troposphere with satellite ozone in the stratosphere and mesosphere. For the ML climatology, the stratosphere-mesosphere portion of the climatological ozone profiles was based on averaging MLS daytime and nighttime limb measurements. The mix of daytime and nighttime measurements led to smearing of the ozone diurnal cycle in the upper stratosphere and lower mesosphere.

The limited amount and sparse spatial coverage of ozonesonde data have led us to now use the NASA Goddard Earth Observing System (GEOS) Global Modeling Initiative (GMI) model as a substitute for the ozonesonde data in the lower atmosphere. The GMI model uses Modern-Era Retrospective Analysis for Research Applications version 2 (MERRA-2) meteorology. We refer to this as the MERRA-2 GMI (hereafter M2GMI) model. 
We have generated a new ozone profile zonal-mean seasonal climatology (MLS/GMI) based on combining MLS $\mathrm{v} 4.2$ and M2GMI ozone profiles which represents an improvement on our previous sonde-satellite ozone climatologies including ML. The earlier climatologies were binned in $10^{\circ}$ latitude bands due mostly to the limited coverage of sondes. In contrast, the new MLS/GMI ozone profile climatology has been binned to $5^{\circ}$ latitude bands by taking advantage of better spatial and temporal coverage of the model output. This new climatology also extends to $80 \mathrm{~km}$ in altitude compared with $65 \mathrm{~km}$ in the previous climatologies. The new MLS/GMI ozone profile climatology is provided for both volume mixing ratio (units of ppmv) and vertical column concentration (Dobson units (DU) $\mathrm{km}^{-1}$ ).

We also generated a new interannual ozone profile climatology based on MLS ozone, Solar Backscatter UltraViolet (SBUV) total ozone and rawinsonde wind data using a rotated empirical orthogonal function (REOF) method. This REOF interannual climatology, just like the MLS/GMI seasonal climatology includes monthly zonal-mean profile ozone concentration (units $\mathrm{DU} \mathrm{km}^{-1}$ ) within $5^{\circ}$ latitude bands and altitudes from 0 to $80 \mathrm{~km}$; however, the REOF climatology represents a long time-dependent record beginning in 1970 rather than a 12-month time record for the MLS/GMI climatology.

The application of the MLS/GMI seasonal climatology by itself or together with the REOF interannual climatology as a priori enables more accurate profile and column ozone retrievals, including improvements for inter-calibrating and merging independent satellite ozone measurements such as for the SBUV Merged Ozone Data Set (MOD) (Frith et al., 2014). The REOF climatology has recently been used to improve the calibration of long-record ozone measurements from ground Umkehr instruments (Irina Petropavlovskikh, personal communication, 2021) and from series of SBUV instruments. The REOF climatology has also recently been used to improve SBUV ozone profile retrievals by adding interannual variability, which nadir instruments can not retrieve due to a coarse vertical resolution. These SBUV ozone profiles with improved interannual variability can be used for the assimilated profile ozone records like one from the Goddard Modeling and Assimilation Office (GMAO) (Krzysztof Wargan, personal communication, 2021).

In the following sections, we describe the data and GMI model output used in our analysis, outline the methods used to construct the MLS/GMI seasonal climatology and REOF climatology, and discuss the properties of the climatologies. We conclude with a summary of our results. Additional details and figures not covered in the main text are included in the Supplement.

\section{Ozone data and M2GMI model simulated ozone}

\subsection{Aura MLS ozone}

The Microwave Limb Sounder (MLS) instrument onboard the Aura spacecraft makes ozone profile measurements along the orbital track during both daytime and nighttime. Aura is in a sun-synchronous orbit; therefore, MLS has nearly complete latitudinal coverage each day between $82^{\circ} \mathrm{S}$ and $82^{\circ} \mathrm{N}$, with local equatorial crossing times of approximately $13: 45$ for the ascending sunlit portion of the orbit and 01:45 for the nighttime descending node.

The MLS instrument is a thermal emission microwave limb sounder that measures vertical profiles of mesospheric, stratospheric and upper tropospheric temperature, ozone and several other trace gases from limb scans made ahead of Aura about $7 \mathrm{~min}$ before the satellite reaches the same point directly below. The MLS instrument primarily uses the $240 \mathrm{GHz}$ microwave band for $\mathrm{v} 4.2$ ozone retrievals which, for recommended scientific applications, extend from 0.0215 to $261 \mathrm{hPa}$ on 38 pressure layers. Vertical spacing for these layers is about $1.3 \mathrm{~km}$ everywhere below $1 \mathrm{hPa}$ and about $2.7 \mathrm{~km}$ at most altitudes above $1 \mathrm{hPa}$. By comparison, the vertical resolution of the ozone retrievals is reported to be $\sim 3 \mathrm{~km}$ extending from $261 \mathrm{hPa}$ up into the mesosphere. Further details regarding the MLS measurements are described by Livesey et al. (2011). The time record for the MLS ozone used in our study was August 2004-December 2016. Given the high quality of MLS ozone in the low mesosphere, we extend the climatology to $80 \mathrm{~km}$ from $65 \mathrm{~km}$, where the ML climatology ended. We use only MLS measurements at the ascending part of the orbit with a local equatorial crossing time at $\sim 13: 45$. For most latitudes, this corresponds to the daytime measurements (solar zenith angle $<90^{\circ}$ ) from MLS, as the daytime data are most appropriate for many passive UV/Vis ozone remote sensing techniques that require daytime measurements. A number of studies of the diurnal ozone variations in stratospheric and mesospheric ozone (Parrish et al., 2014; Frith et al., 2020, and references therein) have demonstrated sizable diurnal ozone variations around $5-10 \mathrm{hPa}$.

\subsection{SBUV MOD total ozone record}

We use MOD total column ozone measurements from the Solar Backscatter UltraViolet (SBUV) v8.6 retrievals as a proxy to reproduce time-dependent interannual variability for the REOF climatology described in Sect. 4. The MOD total ozone dataset (Frith et al., 2014) is comprised of a composite set of measurements from several SBUV instruments. The first instrument was Nimbus-4 BUV (Backscatter UltraViolet) launched in 1970, followed by the second and improved version SBUV on Nimbus-7 launched in October 1978. Starting in 1989, seven SBUV/2 instruments were launched beginning with NOAA-9, followed by NOAA-11, -14, -16, - 
17, -18 and -19 . Currently, this record is extended with the Ozone Mapping and Profiler Suite (OMPS) Nadir Profiler (NP) on board the Suomi National Polar-orbiting Partnership (SNPP) satellite. There are four follow-up OMPS instrumental suites as a part of the Joint Polar Satellite System (JPSS) program (with JPSS-1/NOAA-20 already in operation) that will extend the SBUV-type ozone observations over the next 2 decades. The SBUV instruments retrieve broad ozone profiles from measurements of backscattered solar UV radiation which can be integrated to give total column ozone. All MOD instrument measurements have been processed using the v8.6 retrieval algorithm as described by McPeters et al. (2013) and Bhartia et al. (2013). In this study, we use monthly zonalmean gridded total ozone extending from $90^{\circ} \mathrm{S}$ to $90^{\circ} \mathrm{N}$ at $5^{\circ}$ latitudinal binning (Stacey M. Frith, personal communication, 2021). The MOD total ozone record spans from January 1970 to December 2020 with some temporal gaps, including May 1976-October 1978 due to missing Nimbus-4 BUV measurements.

\subsection{Ozonesonde measurements}

We include balloon-launched ozonesonde measurements for comparison and validation of the M2GMI simulated tropospheric ozone. The used ozonesonde database extends from 2004 to 2019 and includes measurements from the Southern Hemisphere ADditional OZonesondes (SHADOZ) program (Thompson et al., 2017; Witte et al., 2017), the World Ozone and Ultraviolet Data Center (WOUDC) (https: //woudc.org/, last access: 23 September 2021) and the Network for the Detection of Atmospheric Composition Change (NDACC) (http://www.ndsc.ncep.noaa.gov/, last access: 23 September 2021). The ozonesondes provide daily ozone profile concentrations generally a few times per week as a function of altitude; we include ozonesonde data from several dozen global sites. Most of the sonde ozone profile measurements that we use are from electrochemical concentration cell (ECC) instruments. The sonde ozone profiles were integrated vertically each day from the surface to the tropopause to derive tropospheric column ozone (TCO) measurements using the same tropopause pressures as used for M2GMI TCO. Tropopause pressure for both sonde and GMI TCO was derived from National Centers for Environmental Prediction (NCEP) reanalyses based on the World Meteorological Organization (WMO) $2 \mathrm{~K} \mathrm{~km}^{-1}$ temperature lapse-rate definition.

In Sect. 4, we describe construction of the REOF interannual ozone profile climatology that includes monthly tropical quasi-biennial oscillation (QBO) zonal winds. The tropical QBO zonal winds come from the Maldives (January 1970December 1975) and Singapore (January 1976-present) rawinsonde record (Free University of Berlin, https://www.geo. fu-berlin.de/met/, last access: 23 September 2021).

\subsection{MERRA-2 GMI simulated ozone}

The M2GMI simulation is produced with the Goddard Earth Observing System (GEOS) modeling framework (Molod et al., 2015), using winds, temperature and pressure from the MERRA-2 reanalysis (Gelaro et al., 2017). The configuration for this study is a dynamically constrained replay (Orbe et al., 2017) coupled to the Global Modeling Initiative (GMI) stratospheric and tropospheric chemical mechanism (Duncan et al., 2007; Oman et al, 2013; Nielsen et al., 2017). The simulation was run at $\sim 0.5^{\circ}$ horizontal resolution, on the cubed sphere, and output on the same $0.5^{\circ} \times 0.625^{\circ}$ (latitude $\times$ longitude) grid as MERRA-2 from 1980 to 2016 . We refer to Strode et al. $(2015,2020)$ for details of the M2GMI model simulation. The daily M2GMI ozone profiles were averaged monthly and regridded from the original resolution to zonal means in $5^{\circ}$ latitude bands; the original 72 layers of the simulated profile ozone were also remapped to $Z^{*}$ altitudes with $1 \mathrm{~km}$ vertical spacing (Sect. 3.2).

\subsubsection{Evaluation of M2GMI simulated tropospheric ozone}

Ozone profiles generated by the M2GMI simulation have been extensively evaluated in a number of studies. Stauffer et al. (2019) provide a detailed global analysis of M2GMI ozone profiles using comparisons with ozonesondes. On average, they found differences of about $\pm 5 \%$ between M2GMI and sondes in the troposphere from 38 sonde stations from $69^{\circ} \mathrm{S}$ to $79^{\circ} \mathrm{N}$ (their Fig. 1). The largest differences were in the tropics where M2GMI was lower than sonde by up to $10 \%-20 \%$ in low-mid troposphere, but M2GMI was higher than sonde by $40 \%-50 \%$ in the tropical tropopause region; the large percentage differences, however, can be due to relatively low mean background ozone concentrations of only $\sim 1-2 \mathrm{DU} \mathrm{km}^{-1}$. Wargan et al. (2018) compared the annual mean ozone mixing ratio anomalies for 1998-2016 between sondes and M2GMI at several stations for 70,100 and $200 \mathrm{hPa}$. Their comparisons show squared correlations varying from 0.62 to 0.93 , and they concluded that the M2GMI simulation well captures the variability of tropospheric ozone including the upper troposphere-lower stratosphere (UTLS) region. Ziemke et al. (2014) provide an additional evaluation of M2GMI tropospheric ozone by comparing it with ozonesondes, satellite, and Global Modeling and Assimilation Office (GMAO) data assimilation; the M2GMI and sonde daily comparisons from the tropics to high latitudes in both hemispheres (their Figs. 2-7) showed offsets and standard deviations of differences varying $\sim 0-2$ $(\sim 0 \%-7 \%)$ and $4-7 \mathrm{DU}(\sim 15 \%-23 \%)$, respectively. The M2GMI simulated ozone profiles have also been extensively compared with Atmospheric Tomography Mission (ATom) aircraft flight measurements (Bourgeois et al., 2020) for the years 2015 and 2016 (Junhua Liu, personal communication, 2020). The ATom in-flight measurements of the ozone vol- 
ume mixing ratio are found to compare closely with M2GMI simulated ozone, generally within about $\pm 20 \%$ along each of the mission flight paths that included meandering ascent and descent between the near-surface and tropopause each day.

Our study also includes the evaluation of M2GMI simulated tropospheric ozone. Figure 1 compares sonde and M2GMI tropospheric column ozone (TCO) where the sonde and M2GMI measurements have been space-time co-located at the sonde station sites and seasonally averaged for 20042016. The co-location involved matching daily TCO from the sondes with M2GMI daily TCO at a $5^{\circ} \times 5^{\circ}$ gridded resolution interpolated to each sonde latitude-longitude location. As noted in Sect. 2.3, both daily sonde and M2GMI TCO were derived using the same NCEP WMO tropopause pressures.

The M2GMI ozone in Fig. 1 closely simulates the sonde ozone year-round with an exception in the Northern Hemisphere (NH) mid-high latitudes in MAM (March-AprilMay) and JJA (June-July-August) where the simulation tends to underdetermine sonde TCO by $\sim 5 \mathrm{DU}$ or more. Section S3 in the Supplement includes additional discussion and figures regarding the evaluation of M2GMI tropospheric ozone profiles using ozonesondes and surface lidar measurements.

\section{The MLS/GMI seasonal climatology}

The MLS/GMI seasonal climatology product is derived for both volume mixing ratio (units ppmv) and vertical column concentration $\left(\mathrm{DU} \mathrm{km}^{-1}\right)$; the latter has vertical and latitudinal structure that is closely similar to that of ozone number density and ozone partial pressure. Standard deviations are reported for both mixing ratios and column concentrations based upon all available daily ozone profiles over a given month and within every $5^{\circ}$ latitude band. The standard deviations provide a measure of climatological ozone variability and are important for error covariance matrices included as a priori information in retrieval algorithms such as the optimal estimation method of Rodgers (2000). We refer the reader to the Supplement for further discussion and figures involving calculated standard deviations.

\subsection{Global coverage of M2GMI tropospheric ozone compared with sondes}

Our motivation for using M2GMI simulation data is that they provide a better spatial and temporal representation of tropospheric ozone profiles than ozonesondes. The sondes are sparsely distributed over the Earth with generally only a few measured profiles per month for a given station. The limited spatial coverage of sondes is demonstrated in Fig. 2 with the M2GMI mid-tropospheric ozone concentration (ppbv) at height $Z^{*}=5 \mathrm{~km}$ for climatological May. ( $Z^{*}$ is approximately equal to actual altitude and is defined in Sect. 3.2.)

Tropospheric ozone exhibits planetary-scale variability that includes a year-round zonal wave-1 pattern in the tropics (greatest amplitude in September-October) and largescale patterns outside the tropics that vary greatly with season and region (Fishman et al., 1990). The tropical wave 1 in tropospheric ozone originates from regional sources of ozone: lightning, biofuel and biomass burning, stratospheretroposphere exchange (STE), and transport associated with the tropical east-west Walker circulation. In the extratropics, the large planetary-scale features in tropospheric ozone have a strong seasonal dependence, with the seasonal maximum in JJA in the NH and SON (September-OctoberNovember) in the Southern Hemisphere (SH). These seasonal patterns in tropospheric ozone outside the tropics are also due to the combined effects of STE, biofuel, lightning, biomass burning and long-range transport. The global planetary-scale patterns in tropospheric ozone columns were first shown from TOMS/SAGE (Fishman et al., 1990) and TOMS/MLS (Ziemke et al., 1996) satellite measurements. The patterns in the M2GMI tropospheric ozone mixing ratio for $Z^{*}=5 \mathrm{~km}$ in Fig. 2 in the tropics and in the NH are similar to the TCO May pattern from satellite records.

It is apparent from Fig. 2 that the ensemble of ozonesondes is unlikely to effectively represent the zonal-mean tropospheric ozone values due to their limited sampling. For example, the sonde measurements undersample the tropical wave-1 structure in tropospheric ozone in the tropics. Due to the undersampling in the tropical Pacific area, sondes do not capture the very low ozone concentrations of $\sim 10 \mathrm{ppbv}$. This leads to the overestimation of zonal-mean tropospheric ozone in the tropics from the sondes. We will show later that this overdetermination of ML tropospheric ozone in the tropics averages to about 5-10 DU in TCO year-round between $20^{\circ} \mathrm{S}$ and $20^{\circ} \mathrm{N}$. The sondes also tend to miss the high values of ozone in the $\mathrm{NH}$ midlatitudes over the Asian continent (see Fig. 2), thereby introducing a low bias in zonal-mean tropospheric ozone in $\mathrm{NH}$ midlatitudes.

\subsection{Merging MLS and M2GMI ozone profiles}

Simulated ozone volume mixing ratio values from the M2GMI model were merged with ozone volume mixing ratio measurements from MLS to construct the ozone profile seasonal climatology in the format of monthly zonal means. The merging of MLS and M2GMI ozone involved monthly zonalmean ozone profiles for both records in $5^{\circ}$ latitude bands with $Z^{*}$ altitudes of $0-80 \mathrm{~km}$ ( $1 \mathrm{~km}$ increments). For low latitudes and midlatitudes between $40^{\circ} \mathrm{N}$ and $40^{\circ} \mathrm{S}$, the M2GMI and MLS profiles were merged for $Z^{*}$ levels between 13 and $21 \mathrm{~km}(156$ to $49 \mathrm{hPa})$. For latitudes poleward of $40^{\circ}$ in each hemisphere, the profiles were merged slightly lower in the atmosphere, for $Z^{*}$ levels between 8 and $16 \mathrm{~km} \mathrm{(320} \mathrm{to}$ $101 \mathrm{hPa}$ ). Within the merged altitude ranges the climatology 

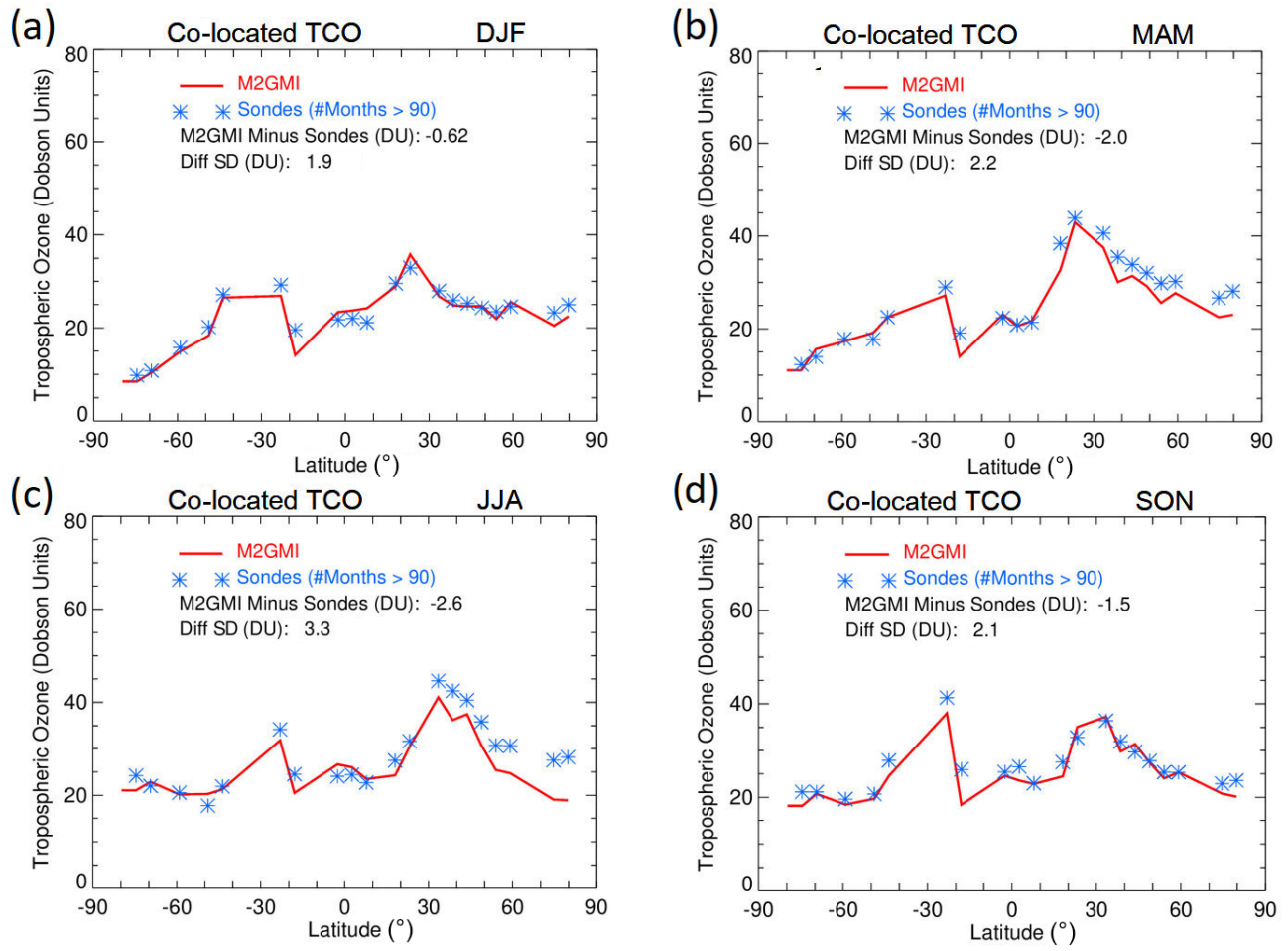

Figure 1. Comparisons between M2GMI simulated (red curves) and ozonesonde (blue asterisks) TCO averaged over 3-month seasons (indicated) for 2004-2016. The M2GMI TCO field is sampled daily at the sonde station locations. All TCO is in Dobson units (DU). The same daily tropopause is used for both M2GMI and sonde to derive TCO, and it is defined according to the WMO $2 \mathrm{Kkm}^{-1}$ lapserate tropopause definition using NCEP temperatures. Included in each panel are mean offsets and standard deviations of TCO seasonal differences.

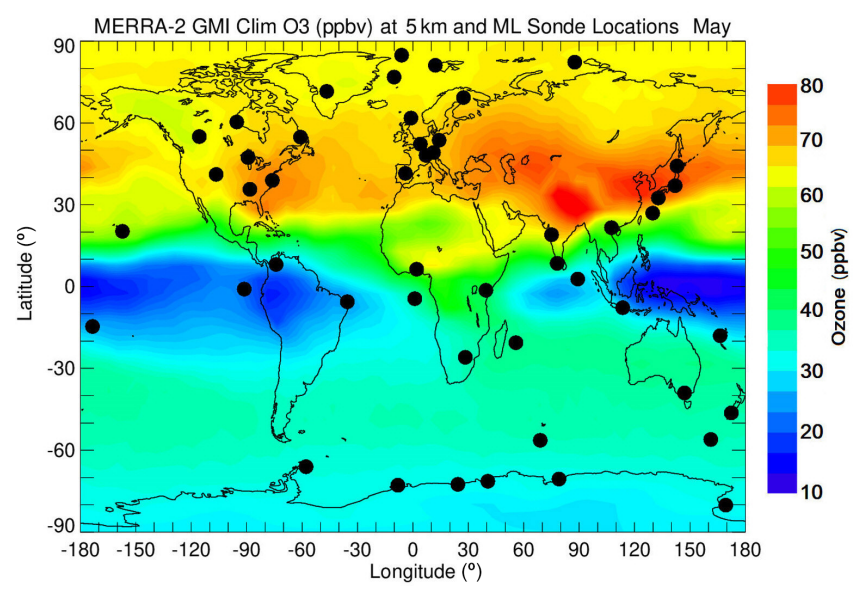

Figure 2. Map of climatological ozone volume mixing ratio (in ppbv) from the M2GMI simulation at $Z^{*}=5 \mathrm{~km}$ altitude (see Sect. 3.2) for the month of May. Blue color indicates areas with an ozone concentration of about $10 \mathrm{ppbv}$, and red color corresponds to regions with $>75$ ppbv. Black circles show the locations of the sonde stations with a long observational record. Data from these stations were used to constrain tropospheric ozone profiles in the ML climatology. is weighted linearly, from $100 \%$ M2GMI at the lowest altitude to $100 \%$ MLS at the highest altitude. Standard deviations were calculated for each climatological ozone value.

As in previous climatologies, the altitude variable used for our climatology is $Z^{*}$, a parameter frequently used in comparisons of atmospheric chemistry models (Park et al., 1999). $Z^{*}$ is in units of kilometers but can be considered a pressure variable. $Z^{*}(\mathrm{~km})$ is defined by $Z^{*}=16 \cdot \log (1013 / P)$, where $P$ is atmospheric pressure (in $\mathrm{hPa}$ ). The altitude spacing for our climatology is $1 \mathrm{~km}$ in $Z^{*}$ units. In an isothermal terrestrial atmosphere, $Z^{*}$ would correspond closely to altitude.

\subsection{Comparisons with the ML climatology}

We first examine basic global patterns of the MLS/GMI seasonal climatology. Figure 3 shows vertical column concentrations $\left(\mathrm{DU} \mathrm{km}^{-1}\right)$ for the climatology by 3 -month season (indicated) for $Z^{*}=0-80 \mathrm{~km}$. Column concentrations in the low stratosphere in both hemispheres are largest during winter-spring and smallest in summer. In both hemispheres, ozone is largest in the winter-spring months due to seasonal transport from the tropics to the extra-tropics during this period (i.e., the Brewer-Dobson circulation) and longer lifetimes for ozone in the low stratosphere. The highest ozone amounts in Fig. 3 are $\sim 18-20 \mathrm{DU} \mathrm{km}^{-1}$ in the NH around 
$20 \mathrm{~km}$ during winter and spring. In the troposphere, very low ozone density of less than $2 \mathrm{DU} \mathrm{km}^{-1}$ occurs in the tropics year-round.

While the basic characteristics of stratospheric ozone in Fig. 3 are important to note, our main focus is to compare tropospheric ozone in Fig. 3 with the ML sonde ozone climatology. Because the ML climatology uses sparsely sampled sonde measurements to estimate zonal means in the troposphere, it is possible that there may be substantial differences.

Figure 4 shows the difference between ML and MLS/GMI zonal-mean profile ozone by season, plotted as $Z^{*}$ altitude versus latitude. Only $Z^{*}$ levels $0-30 \mathrm{~km}$ are included in Fig. 4 to highlight differences in ozone profiles used for the troposphere and the low stratosphere merging region. Year-round positive differences in the tropics in Fig. 4 suggest that ML is always too large in the low-mid troposphere compared with M2GMI due to the absence of ML sonde measurements in the Pacific region where tropospheric ozone is low (e.g., Fig. 2). At latitudes around $\pm 35^{\circ}$ and elsewhere in the low stratosphere merging region in Fig. 4, there are anomalous differences from -0.5 up to $+1.5 \mathrm{DU} \mathrm{km}^{-1}$; these sharp patterns are ascribed to sonde sampling issues for the ML climatology. In the boundary layer throughout the NH extratropics during winter (i.e., upper-left panel in Fig. 4), the M2GMI ozone is higher than sondes by $\sim 0.5$ to $1 \mathrm{DU} \mathrm{km}^{-1}$. These latter differences are attributed to a known model issue related to underestimating surface deposition over cold surfaces (Jaegle et al., 2018), which is most prominent in the $\mathrm{NH}$ boundary layer during winter. When compared with ML in Fig. 4, the model in this region overdetermines the ozone column in DJF (December-January-February) by about 2 DU.

Line plots of seasonal differences (ML minus MLS/GMI) of integrated ozone columns are shown in Fig. 5 for $0-8 \mathrm{~km}$ (Fig. 5a) and 0-16 km (Fig. 5b). These line plots are determined from Fig. 4 by summing the $1 \mathrm{~km}$ layers of ML minus MLS/GMI differences. In the tropics, the $0-16 \mathrm{~km}$ integrated column in Fig. 5b represents the total troposphere (i.e., TCO) with ML larger than MLS/GMI by about $10 \mathrm{DU}$ year-round. Comparison with the $0-8 \mathrm{~km}$ columns in Fig. $5 \mathrm{a}$ shows that these differences in the tropics originate mostly from the lower troposphere, which is consistent with all four panels in Fig. 4. Outside the tropics in Fig. 5, there are seasonal offset differences in the $\mathrm{NH}$ of up to -5 to $-10 \mathrm{DU}$ during DJF. Part of the reason for the ML minus MLS/GMI biases in Fig. 5 is sonde undersampling for the ML climatology, particularly in the tropics, as noted for Fig. 4. The sonde undersampling also creates the sharp (nonphysical) variability seen between adjacent latitude bins in Fig. 5 .

\section{An interannual ozone profile climatology}

The MLS/GMI seasonal climatology captures the vertical shape of zonal-mean ozone profiles by season and latitude in both the troposphere and stratosphere. However, interannual processes such as the QBO produce sizable changes in the vertical ozone distribution in stratospheric ozone from year to year. To capture these variations, we have constructed a global time-dependent climatology of stratospheric ozone that represents ozone interannual variability. This climatology can be used either independently or added to the MLS/GMI seasonal climatology, depending on the particular application.

The derivation of the interannual ozone climatology is lengthy and is discussed in detail in the Supplement. In this section, we provide only a short overview of the methodology and discuss the final product. The interannual ozone climatology is constructed using a method that includes an REOF analysis as described by Richman (1986, and references therein). With our approach, vertical information for the climatology comes from an REOF analysis of MLS ozone profiles, while month-to-month time dependence follows by coupling the REOF analysis time coefficients with SBUV MOD total ozone and tropical QBO zonal winds. The time period for the REOF climatology depends on the availability of total ozone and tropical QBO winds. The time period for this climatology is 1970-2018 (588 consecutive months) with gaps present due to some missing MOD total ozone including Nimbus-4 measurements in the 1970s. We plan to periodically extend this REOF climatology when zonal wind and MOD total ozone data become available. Before applying the REOF approach, an empirical orthogonal function (EOF) method (Kutzbach, 1967, and references therein) was applied to MLS ozone anomaly profiles to derive repeatable interannual patterns in the ozone vertical distribution; that is, the EOF analysis was applied to MLS monthly zonal-mean ozone profile anomalies derived by removing seasonal cycles between August 2004 and December 2016. All MLS ozone and anomaly ozone profiles were binned into $5^{\circ}$ latitude bands ( 36 bands for $90^{\circ} \mathrm{S}-90^{\circ} \mathrm{N}$, similar to MLS/GMI climatology) between 1 and $261 \mathrm{hPa}$ (30 pressure levels).

The main challenge of EOF analysis is interpretation of derived EOFs and EOF time coefficients and their attribution to specific geophysical processes. As described in the Supplement, the construction of this REOF climatology required only total ozone and tropical stratospheric zonal wind time series to explain most of the stratospheric ozone profiles variability (total EOF variance). We used MLS ozone anomalies expressed as ozone partial pressure for the REOF analysis rather than ozone mixing ratio because it helped to attribute the REOF-1 time coefficient directly to total ozone column measurements at all latitudes. The first REOF vector with the MOD total ozone time series as a proxy explains about $50 \%-70 \%$ of the interannual ozone variability. Next, we derived a second REOF-2 that we attributed to the QBO and used the equatorial zonal wind time series as a proxy for REOF-2. The sum of these two REOFs explains about $70 \%-80 \%$ of the interannual variability in deseasonalized 

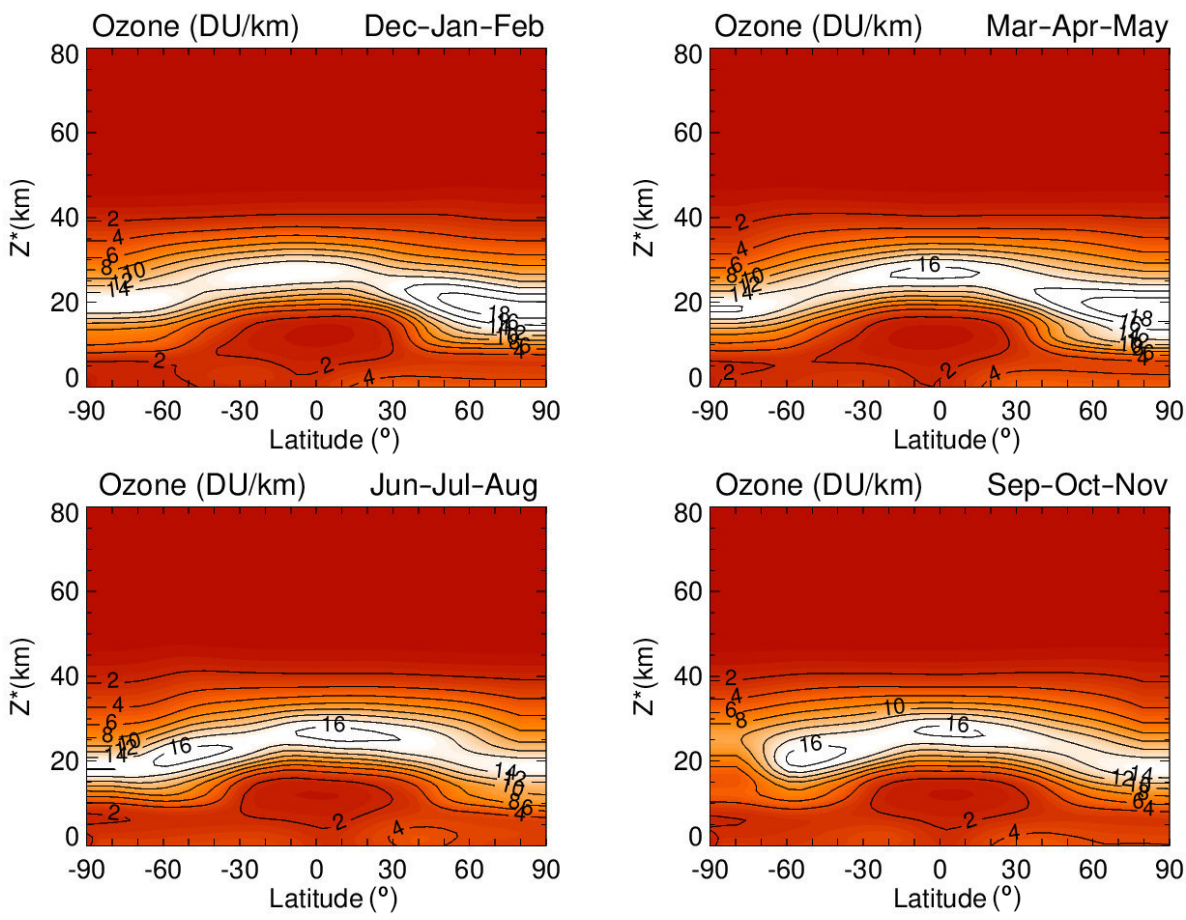

Figure 3. Meridional cross sections of derived zonal-mean vertical ozone concentration (units DU km ${ }^{-1}$ ) for the MLS/GMI seasonal climatology. This 12-month climatology is averaged over 3-month seasons (indicated) for 2004-2016 and is binned for $5^{\circ}$ latitude bands and $Z^{*}$ levels from 0 to $80 \mathrm{~km}$ at $1 \mathrm{~km}$ spacing (see text).
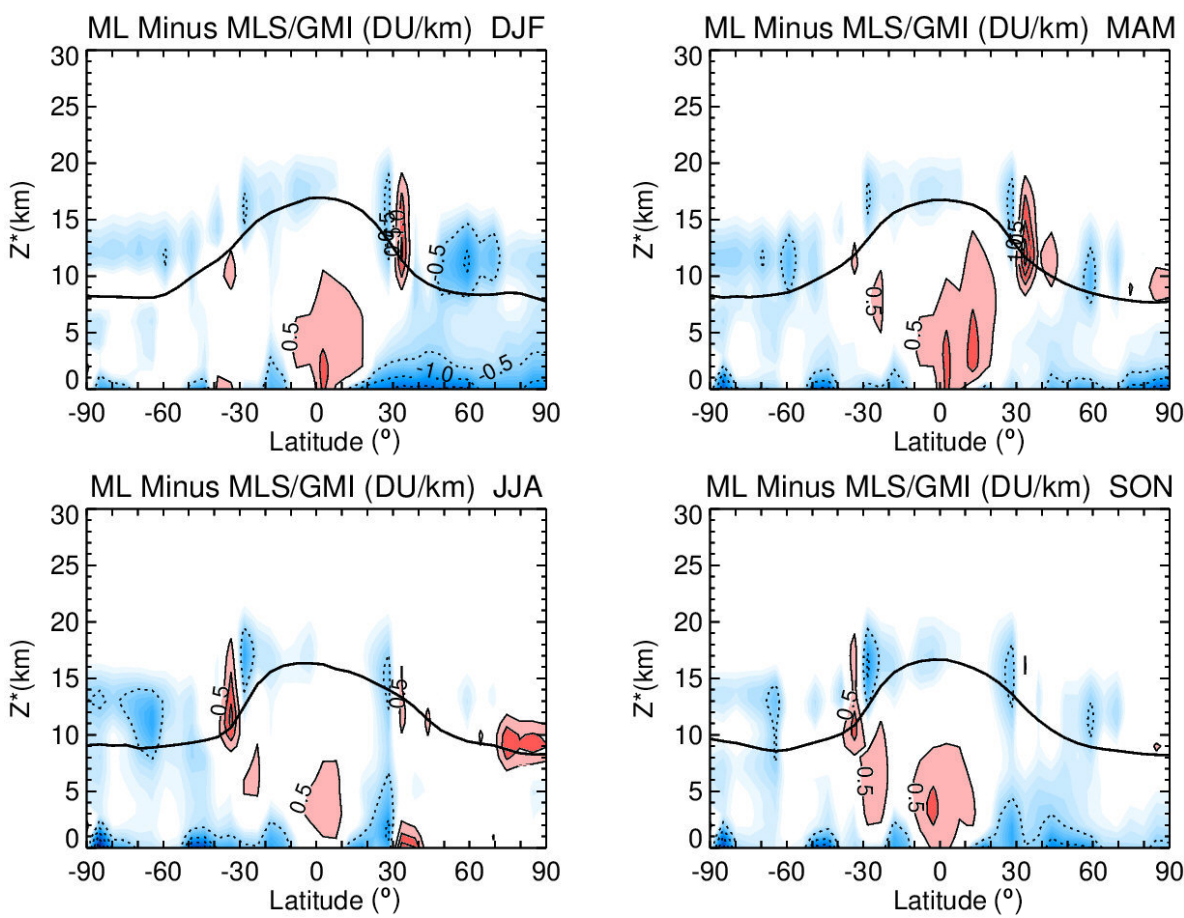

Figure 4. Meridional cross sections of ML minus MLS/GMI climatologies of ozone column concentration (DUkm $\left.{ }^{-1}\right)$. These differences are averaged over 3-month seasons (indicated) for 2004-2016 and are binned for $10^{\circ}$ latitude bands and $Z^{*}$ levels from 0 to $30 \mathrm{~km}$ at $1 \mathrm{~km}$ spacing. Contour levels (indicated) are at $0.5 \mathrm{DU} \mathrm{km}^{-1}$ increments: blue and dashed contours mean negative, and pink and red solid contours mean greater than $0.5 \mathrm{DU} \mathrm{km}^{-1}$. The black line indicates tropopause height according to the WMO $2 \mathrm{~K} \mathrm{~km}^{-1}$ lapse-rate tropopause definition using NCEP temperatures. White color denotes zero differences. 
(a)

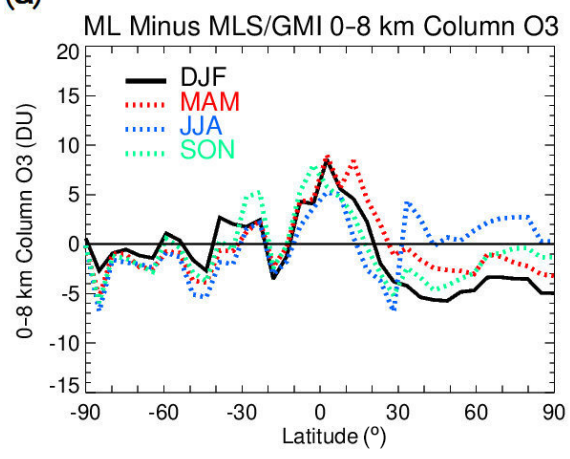

(b)

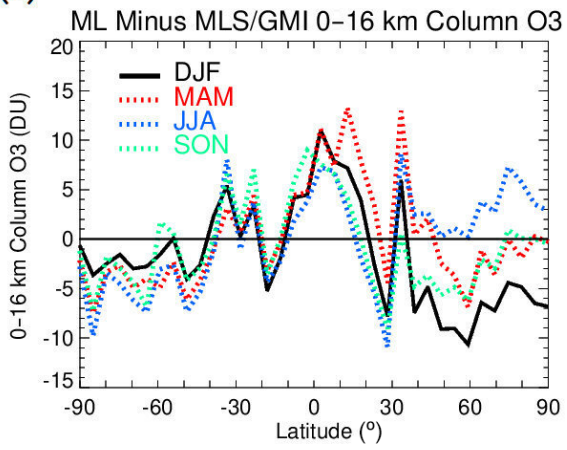

Figure 5. (a) Line plots of seasonal differences of ML minus MLS/GMI integrated ozone columns for 0-8 km. The differences are averaged over 3-month seasons (indicated by DJF, MAM, JJA and SON). Panel (b) is the same as panel (a) but for 0-16 km ozone columns.

MLS zonal-mean ozone profiles. As only MLS profiles are used to constrain the vertical shapes of the REOFs and time coefficients are described by total ozone and zonal winds, this REOF climatology can be used in the future (even after MLS stops operating) or can be extended into the past to the pre-Aura time period whenever total column ozone and wind data are available.

The REOF climatology was finally converted from the ozone partial pressures defined at 30 MLS levels to volume mixing ratio (ppmv) and partial ozone column $\left(\mathrm{DU} \mathrm{km}^{-1}\right)$ at the $1 \mathrm{~km} Z^{*}$ levels (defined in Sect. 3.2) identical to the MLS/GMI climatology. The REOF climatological values at levels below $\sim 9 \mathrm{~km}$ and above $\sim 48 \mathrm{~km}$ are very small in contributing to interannual variability of ozone and are set to zero. As the REOF climatology uses zonal wind and total ozone time series that can have long-term trends, we applied a very low frequency (VLF) digital low-pass filter to the final derived REOF climatology to remove long-term decadal variability. This was done to ensure that the climatology captures only interannual variability in monthly zonal-mean ozone anomaly profiles without inducing decadal trends if used as a priori in ozone retrieval. The frequency response of the applied VLF digital filter (Stanford et al., 1993) is exactly 0.0 (1.0) at zero (Nyquist) frequency with an amplitude of 0.5 at a frequency of 0.00333 per month; the filter was also designed to have zero phase shift at all frequencies.

We demonstrate that the REOF climatology does very well in capturing interannual variability of monthly zonal-mean stratospheric ozone. The high vertical resolution of MLS ozone limb measurements of $\sim 3 \mathrm{~km}$ resolves much of the vertical variability of ozone caused by low-frequency and episodic processes such as the QBO, extra-tropical stratospheric warmings and other year-round planetary-scale wave events (e.g., Ziemke et al., 2014, and references therein). Many nadir instrument ozone profile retrievals have coarse vertical resolution of $\sim 6$ to $10 \mathrm{~km}$ or greater (such as from SBUV or the Ozone Monitoring Instrument, OMI) and can-

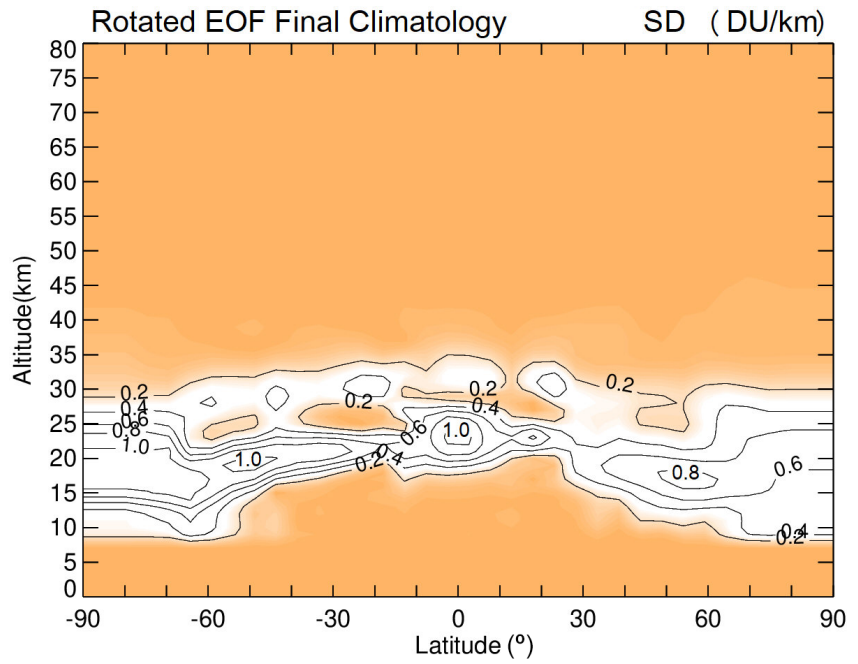

Figure 6. Temporal standard deviation (in $\mathrm{DU} \mathrm{km}^{-1}$ ) for 1970 2018 for the final REOF ozone climatology (i.e., Eq. S10 in the Supplement). The interannual variability in the tropical low latitudes is almost entirely due to the QBO. Interannual variability in the extratropics comes from the QBO coupled with other non-QBO-related interannual variability.

not do nearly as well at resolving vertical changes in stratospheric ozone.

The magnitude of interannual variability in profile ozone, captured by the REOF climatology, is shown in Fig. 6 as calculated standard deviations (in DU km ${ }^{-1}$ ) for the 1970-2018 period. In the tropical low latitudes from $10^{\circ} \mathrm{S}$ to $10^{\circ} \mathrm{N}$, the main source of interannual variability is the QBO. However, larger interannual variability occurs in the SH extra-tropics due to the QBO and additional dynamical sources. In an effort to understand the contribution of non-QBO processes to the interannual variability, we also generated a climatology using only equatorial QBO zonal winds as a proxy (see Fig. S4 in the Supplement). When compared with the REOF climatology in Fig. 6, only a very small fraction of interan- 
(a)
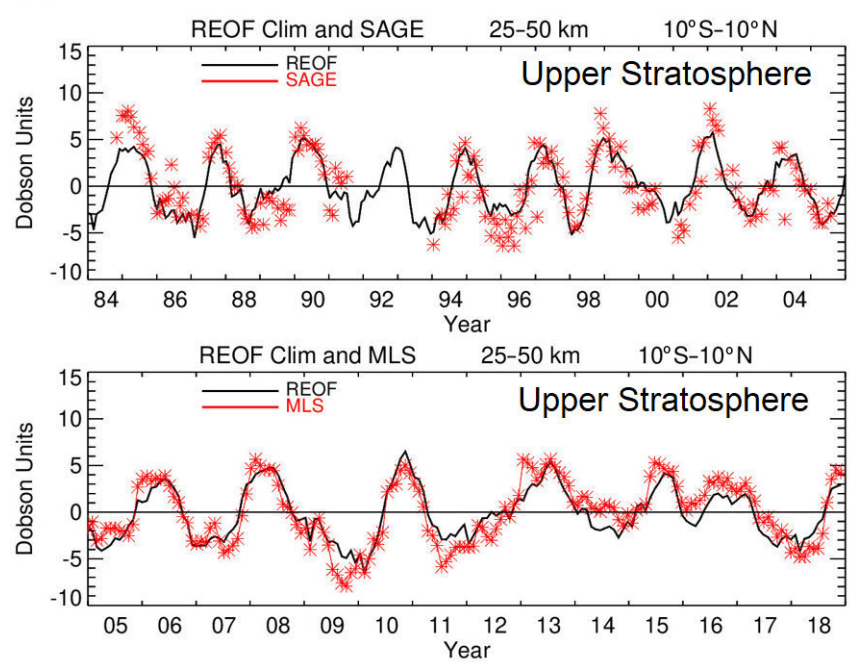

(b)
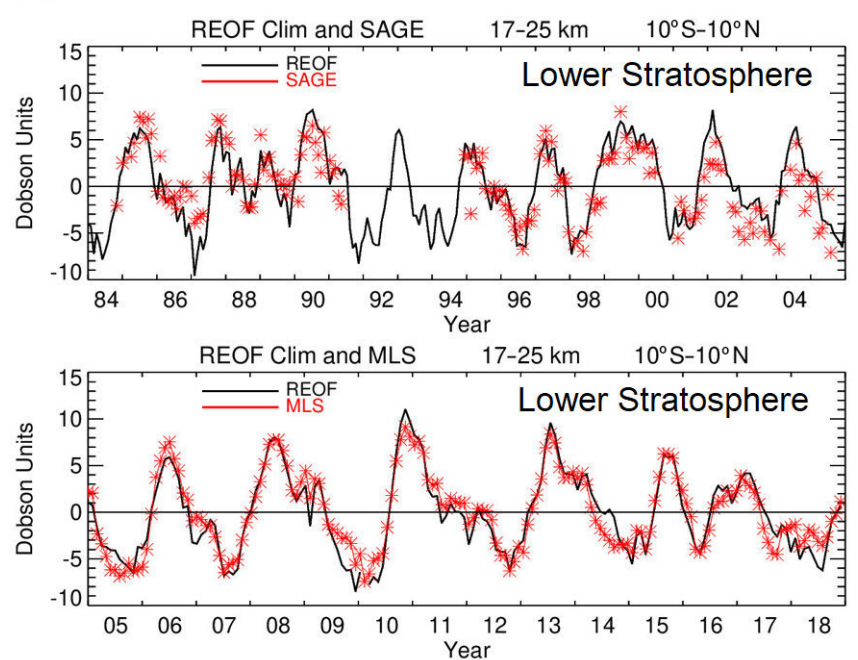

Figure 7. (a) The top panel is zonal-mean upper-stratospheric column ozone (in Dobson units) for the REOF climatology (black curve) and deseasonalized SAGE II (red asterisks) spanning from 1984 to 2005 and averaged between $10^{\circ} \mathrm{S}$ and $10^{\circ} \mathrm{N}$. The SAGE data are deseasonalized monthly zonal means. All column amounts are calculated by integrating ozone profiles for $Z^{*}=25-50 \mathrm{~km}(\sim 28$ to $1 \mathrm{hPa})$. The bottom panel is the same as the top panel but with MLS in place of SAGE and for the time period from 2005 to 2018. The panels in (b) are the same as those in (a) but for the lower stratosphere with $Z^{*}=17-25 \mathrm{~km}(\sim 88$ to $28 \mathrm{hPa})$.

nual variability is captured in the extra-tropics for the QBOonly climatology.

The long record of the REOF interannual ozone profile climatology has been compared with deseasonalized ozone profile measurements from SAGE II and Aura MLS for 19842018 (Fig. 7). The top panel in Fig. 7a shows comparisons of upper-stratospheric column ozone anomalies $\left(Z^{*}=25\right.$ $50 \mathrm{~km}$ ) between REOF (black curve) and SAGE (red asterisks) for the years from 1984 to 2005 in the tropics $\left(10^{\circ} \mathrm{S}-\right.$ $\left.10^{\circ} \mathrm{N}\right)$. The bottom panel in Fig. 7a shows a similar comparison between REOF and MLS for 2005-2018. Figure 7b is the same as in Fig. 7a but for the lower stratosphere $\left(Z^{*}=17\right.$ $25 \mathrm{~km})$.

The SAGE II sampling of ozone columns in Fig. 7 is sparse, averaging $\sim 2-3 \mathrm{~d}$ of measurements for a given month in the $10^{\circ} \mathrm{S}-10^{\circ} \mathrm{N}$ latitude band shown. This means that the monthly SAGE measurements in Fig. 7 are more representative of daily profiles than monthly means. Ozone profiles on a daily basis in the tropics are distorted by propagating tropical waves with periods of days to weeks such as Kelvin waves, equatorial Rossby waves and mixed Rossbygravity waves (e.g., Timmermans et al., 2005; Ziemke and Stanford, 1994). As a result, the upper- and lowerstratospheric columns in Fig. 7 for SAGE II will have noisy month-to-month variations of several Dobson units because of these tropical waves. The Supplement includes further discussion and more figures relating to the REOF climatology.

\section{Summary}

We have produced a new MLS/GMI seasonal ozone profile climatology by combining ozone profiles from the M2GMI model simulation with MLS v4.2 measurements. M2GMI is used primarily for tropospheric ozone and MLS for stratospheric ozone, with the two ozone profile datasets blended together in the low stratosphere; the result is a merged zonalmean 12-month global ozone profile climatology at a $5^{\circ}$ latitudinal resolution with a $Z^{*}$ altitude range of $0-80 \mathrm{~km}$ (1 km vertical sampling). Our main interest in generating the MLS/GMI climatology is to use it as a priori information in satellite ozone retrieval algorithms. However, it is also useful as a baseline for evaluating various modeled or measured ozone seasonal and interannual variability, and in studies involving corresponding ozone radiative forcing as inferred from atmospheric radiative transfer calculations.

In previous studies, we generated several ozone profile climatologies based on combining ozonesondes with either SAGE or MLS satellite measurements (e.g., McPeters et al., 2007; McPeters and Labow, 2012; Labow et al., 2015). We have compared the new MLS/GMI climatology in detail with the ML climatology (of McPeters and Labow, 2012) that used ozonesondes for tropospheric ozone profiles. The M2GMI model simulation provides an improved ozone climatology for the troposphere compared with the ML climatology due to the fact that it has much better spatial and temporal coverage than the sondes.

We also developed a time-dependent climatology of monthly zonal-mean profile ozone anomalies representing 
interannual variability. This interannual climatology was constructed using a rotational EOF analysis of Aura MLS monthly zonal-mean profile ozone anomalies from August 2004 to December 2016 within each $5^{\circ}$ latitude band. The analysis shows that the first two leading EOFs explain $70 \%-80 \%$ of interannual variability of profile ozone at all latitudes. Furthermore, total ozone and tropical zonal wind time series correlate well with the two leading EOF coefficient time series and were used as proxies to extend information outside the Aura MLS time range. We used these relationships to reconstruct anomalies at a $5^{\circ}$ latitudinal resolution for $Z^{*}=0-80 \mathrm{~km}$ and 1970-2018. This REOF timedependent climatology was compared to a similar climatology based on only tropical QBO winds. The advantage of the REOF climatology is that it allows for a much more thorough representation of interannual variability of stratospheric ozone than just the QBO.

The REOF time-dependent climatology of ozone profile anomalies can be easily added to the MLS/GMI seasonal climatology to simulate both seasonal and interannual variability of stratospheric ozone. We note that both the MLS/GMI 12-month climatology and the REOF climatology were generated using Aura time period MLS ozone measurements, and neither of them account for long-term trends in stratospheric ozone.

Code availability. Codes used to generate the ozone climatologies along with the analyses in this study are available upon personal request to Jerald R. Ziemke (jerald.r.ziemke@ nasa.gov).

Data availability. The data description for MLS v4.2 ozone and links to the data can be obtained from the following websites: https://mls.jpl.nasa.gov/ (NASA MLS division, 2021) and https://disc.gsfc.nasa.gov/ (NASA MLS science research group, 2021). The MERRA-2 GMI model description and access are available from https://acd-ext.gsfc.nasa.gov/Projects/GEOSCCM/ MERRA2GMI/ (Code 614 GMI modeling group, 2021). The MOD total ozone measurements are available from https://acd-ext.gsfc. nasa.gov/Data_services/merged/ (Code 614 ozone trends group, 2021). Tropical QBO winds were provided by the Free University of Berlin (2021): https://www.geo.fu-berlin.de/met/ag/strat/produkte/ qbo/qbo.dat. The seasonal and interannual climatology products derived from our study are available for the general public using the direct links on the NASA website: https://avdc.gsfc.nasa.gov/ (last access: 23 September 2021).

Supplement. The supplement related to this article is available online at: https://doi.org/10.5194/amt-14-6407-2021-supplement.

Author contributions. JRZ is the lead author of the paper and was responsible for writing the paper and data analysis that included the development of the REOF interannual climatology and validation. GJL helped to write the paper and was responsible for the devel- opment of the MLS/GMI seasonal climatology and providing the ozonesonde database used for validation. NAK also helped to write the paper and was responsible for the analyses of total ozone and tropospheric ozone, and the derived climatologies. RDM and PKB, as experts on ozone algorithms, contributed to the analysis that included their extensive experience in developing ozone climatologies and applications involving the rotational EOF technique. LDO helped with the analysis and writing the paper, especially regarding the M2GMI simulated ozone. SMF and DPH played key roles involving the analysis of the derived seasonal and REOF climatologies.

Competing interests. The contact author has declared that neither they nor their co-authors have any competing interests.

Disclaimer. Publisher's note: Copernicus Publications remains neutral with regard to jurisdictional claims in published maps and institutional affiliations.

Acknowledgements. We thank the NASA Jet Propulsion Laboratory MLS team for the MLS v4.2 ozone dataset, and the SHADOZ, WOUDC and NDACC personnel for providing the extensive ozonesonde measurements that we used for our study. We also thank the NASA MAP program for supporting the MERRA-2 GMI simulation and the NASA Center for Climate Simulation (NCCS) for providing high-performance computing resources. Special thanks go to the NASA GMI group, especially Sarah Strode, regarding the MERRA-2 GMI simulation.

Financial support. This research has been supported by the NASA programmatic fund "Long-term ozone trends" (project no. WBS 479717). Jerald R. Ziemke and Natalya A. Kramarova were also supported by the NASA ROSES proposal "Improving total and tropospheric ozone column products from EPIC on DSCOVR for studying regional scale ozone transport" (grant no. 18-DSCOVR180011, DSCOVR Science Team). Gordon J. Labow, Stacey M. Frith and David P. Haffner were supported under NASA contract NNG17HP01C. Luke D. Oman was supported by the NASA "Modeling, Analysis, and Prediction” (MAP) program.

Review statement. This paper was edited by Mark Weber and reviewed by two anonymous referees.

\section{References}

Bhartia, P. K., McPeters, R. D., Flynn, L. E., Taylor, S., Kramarova, N. A., Frith, S., Fisher, B., and Deland, M.: Solar Backscatter UV (SBUV) total ozone and profile algorithm, Atmos. Meas. Tech., 6, 2533-2548, https://doi.org/10.5194/amt-6-2533-2013, 2013.

Bourgeois, I., Peischl, J., Thompson, C. R., Aikin, K. C., Campos, T., Clark, H., Commane, R., Daube, B., Diskin, G. W., Elkins, J. W., Gao, R.-S., Gaudel, A., Hintsa, E. J., Johnson, B. J., Kivi, 
R., McKain, K., Moore, F. L., Parrish, D. D., Querel, R., Ray, E., Sánchez, R., Sweeney, C., Tarasick, D. W., Thompson, A. M., Thouret, V., Witte, J. C., Wofsy, S. C., and Ryerson, T. B.: Global-scale distribution of ozone in the remote troposphere from the ATom and HIPPO airborne field missions, Atmos. Chem. Phys., 20, 10611-10635, https://doi.org/10.5194/acp-2010611-2020, 2020.

Code 614 GMI modeling group: MERRA-2 GMI model results, NASA Goddard Space Flight Center, available at: https://acd-ext. gsfc.nasa.gov/Projects/GEOSCCM/MERRA2GMI/, last access: 16 April 2021.

Code 614 ozone trends group: MOD total ozone dataset, Goddard Space Flight Center, available at: https://acd-ext.gsfc.nasa.gov/ Data_services/merged/, last access: September 2021.

Duncan, B. N., Strahan, S. E., Yoshida, Y., Steenrod, S. D., and Livesey, N.: Model study of the cross-tropopause transport of biomass burning pollution, Atmos. Chem. Phys., 7, 3713-3736, https://doi.org/10.5194/acp-7-3713-2007, 2007.

Fishman, J., Watson, C. E., Larsen, J. C., and Logan, J. A.: Distribution of tropospheric ozone determined from satellite data, J. Geophys. Res., 95, 3599-3617, 1990.

Free University of Berlin: Tropical QBO zonal, available at: https://www.geo.fu-berlin.de/met/ag/strat/produkte/qbo/qbo. dat, last access: 23 September 2021.

Frith, S. M., Kramarova, N. A., Stolarski, R. S., McPeters, R. D., Bhartia, P. K., and Labow, G. J.: Recent changes in total column ozone based on the SBUV Version 8.6 Merged Ozone Data Set, J. Geophys. Res.-Atmos., 119, 9735-9751, https://doi.org/10.1002/2014JD021889, 2014.

Frith, S. M., Bhartia, P. K., Oman, L. D., Kramarova, N. A., McPeters, R. D., and Labow, G. J.: Model-based climatology of diurnal variability in stratospheric ozone as a data analysis tool, Atmos. Meas. Tech., 13, 2733-2749, https://doi.org/10.5194/amt-13-2733-2020, 2020.

Gelaro, R., McCarty, W., Suárez, M. J., Todling, R., Molod, A., Takacs, L., Randles, C. A., Darmenov, A., Bosilovich, M. G., Reichle, R., Wargan, K., Coy, L., Cullather, R., Draper, C., Akella, S., Buchard, V., Conaty, A., da Silva, A. M., Gu, W., Kim, G., Koster, R., Lucchesi, R., Merkova, D., Nielsen, J. E., Partyka, G., Pawson, S., Putman, W., Rienecker, M., Schubert, S. D., Sienkiewicz, M., and Zhao, B.: The Modern-Era Retrospective Analysis for Research and Applications, Version 2 (MERRA-2), J. Climate, 30, 5419-5454, https://doi.org/10.1175/JCLI-D-160758.1, 2017.

Jaeglé, L., Shah, V., Thornton, J. A., Lopez-Hilfiker, F. D., Lee, B. H., McDuffie, E. E., Fibiger, D., Brown, S. S., Veres, P., Sparks, T. L., Ebben, C. J., Wooldridge, P. J., Kenagy, H. S., Cohen, R. C., Weinheimer, A. J., Campos, T. J., Montzka, D. D., Digangi, J. P., Wolfe, G. M., Hanisco, T., Schroder, J. C., and Campuzano P.: Nitrogen oxides emissions, chemistry, deposition, and export over the Northeast United States during the WINTER aircraft campaign, J. Geophys. Res.-Atmos., 123, 12368-12393, https://doi.org/10.1029/2018JD029133, 2018.

Kutzbach, J. E.: Empirical eigenvectors of sea-level pressure, surface temperature and precipitation complexes over North America, J. App. Meteorol., 6, 791-802, https://doi.org/10.1175/15200450(1967)006<0791:EEOSLP>2.0.CO;2, 1967.

Labow, G. J., Ziemke, J. R., McPeters, R. D., Haffner, D. P., and Bhartia, P. K.: A total ozone-dependent ozone pro?le climatology based on ozonesondes and Aura MLS data, J. Geophys. Res.-Atmos., 120, 2537-2545, https://doi.org/10.1002/2014JD022634, 2015.

Livesey, N. J., Read, W. G., Froidevaux, L., Lambert, A., Manney, G. L., Pumphrey, H. C., Santee, M. L., Schwartz, M. J., Wang, S., Cofield, R. E., Cuddy, D. T., Fuller, R. A., Jarnot, R. F., Jiang, J. H., Knosp, B. W., Stek, P. C., Wagner, P. A., and Wu, D. L.: EOS MLS Version 3.3 Level 2 data quality and description document, Tech. Rep., Jet Propulsion Laboratory, available at: http://mls.jpl. nasa.gov/ (last access: 23 September 2021), 2011.

McPeters, R. D. and Labow, G. J.: Climatology 2012: An MLS and sonde derived ozone climatology for satellite retrieval algorithms, J. Geophys. Res., 117, https://doi.org/10.1029/2011JD017006, 2012.

McPeters, R. D., Labow, G. J., and Logan, J. A.: Ozone climatological profiles for satellite retrieval algorithms, J. Geophys. Res., 112, D05308, https://doi.org/10.1029/2005JD006823, 2007.

McPeters, R. D., Bhartia, P. K., Haffner, D., Labow, G. J., and Flynn, L.: The version 8.6 SBUV ozone data record: An overview, J. Geophys. Res., 118, 8032-8039, https://doi.org/10.1002/jgrd.50597, 2013.

Molod, A., Takacs, L., Suarez, M., and Bacmeister, J.: Development of the GEOS-5 atmospheric general circulation model: evolution from MERRA to MERRA2, Geosci. Model Dev., 8, 1339-1356, https://doi.org/10.5194/gmd-8-1339-2015, 2015.

NASA MLS division: MLS data, JPL, available at: https://mls.jpl. nasa.gov/, last access 23 September 2021.

NASA MLS science research group: MLS data, NASA Goddard Space Flight Center, available at: https://disc.gsfc.nasa.gov/, last access: 16 April 2021.

Nielsen, J. E., Pawson, S., Molod, A., Auer, B., da Silva, A. M., Douglass, A. R., Duncan, B. N., Liang, Q., Manyin, M., Oman, L., D., Putman, W., Strahan, S. E., and Wargan, K.: Chemical mechanisms and their applications in the Goddard Earth Observing System (GEOS) earth system model, J. Adv. Model. Earth Syst., 9, 3019-3044, https://doi.org/10.1002/2017MS001011, 2017.

Oman, L. D., Douglass, A. R., Ziemke, J. R., Rodriguez, J. M., Waugh, D. W., and Nielsen, J. E.: The ozone response to ENSO in Aura satellite measurements and a chemistry-climate simulation, J. Geophys. Res., 118, 965-976, https://doi.org/10.1029/2012JD018546, 2013.

Orbe, C., Oman, L. D., Strahan, S. E., Waugh, D. W., Pawson, S., Takacs, L. L., and Molod, A. M.: Large-Scale Atmospheric Transport in GEOS Replay Simulations, J. Adv. Model. Earth Sy., 9, 2545-2560, 2017.

Park, J. H., Ko, M. K., Jackman, C. H., Plumb, R. A., Kaye, J. A., and Sage, K. H.: Models and Measurements Intercomparison II, NASA Tech. Memo., NASA/TM-1999-209554, Hanover, MD, 502 pp., 1999.

Parrish, A., Boyd, I. S., Nedoluha, G. E., Bhartia, P. K., Frith, S. M., Kramarova, N. A., Connor, B. J., Bodeker, G. E., Froidevaux, L., Shiotani, M., and Sakazaki, T.: Diurnal variations of stratospheric ozone measured by ground-based microwave remote sensing at the Mauna Loa NDACC site: measurement validation and GEOSCCM model comparison, Atmos. Chem. Phys., 14, 7255-7272, https://doi.org/10.5194/acp-14-7255-2014, 2014.

Richman, M. B.: Rotation of principal components, J. Climate, 6, 293-335, https://doi.org/10.1002/joc.3370060305, 1986. 
Rodgers, C. D.: Inverse methods for atmospheric sounding: theory and practice, World Scientific Pupblishing Co., 238 pp., London, United Kingdom, 2000.

Stanford, J. L., Ziemke, J. R., and Gao, S. Y.: Stratospheric circulation features deduced from SAMS constituent data, J. Atmos. Sci., 50, 226-246, 1993.

Stauffer, R. M., Thompson, A. M., Oman, L. D., and Strahan, S. E.: The effects of a 1998 observing system change on MERRA-2based ozone profile simulations, J. Geophys. Res.-Atmos., 124, 7429-7441, https://doi.org/10.1029/2019JD030257, 2019.

Strode, S. A., Rodriguez, J. M., Logan, J. A., Cooper, O. R., Witte, J. C., Lamsal, L. N., Damon, M., Van Aartsen, B., Steenrod, S. D., and Strahan, S. E.: Trends and variability in surface ozone over the United States, J. Geophys. Res.-Atmos., 120, 9020-9042, https://doi.org/10.1002/2014JD022784, 2015.

Strode, S. A., Wang, J. S., Manyin, M., Duncan, B., Hossaini, R., Keller, C. A., Michel, S. E., and White, J. W. C.: Strong sensitivity of the isotopic composition of methane to the plausible range of tropospheric chlorine, Atmos. Chem. Phys., 20, 8405-8419, https://doi.org/10.5194/acp-20-8405-2020, 2020.

Thompson, A. M., Witte, J. C., Sterling, C., Jordan, A., Johnson, B. J., Oltmans, S. J., Fujiwara, M., Vömel, H., Allaart, M., Piters, A., Coetzee, G. J. R., Posny, F., Corrales, E., Andres Diaz, J., Félix, C., Komala, N., Lai, N., Maata, M., Mani, F., Zainal, Z., Ogino, S.-Y., Paredes, F., Luiz Bezerra Penha, T., Raimundo da Silva, F., Sallons-Mitro, S., Selkirk, H. B., Schmidlin, F. J., Stuebi, R., and Thiongo, K.: First reprocessing of Southern Hemisphere Additional Ozonesondes (SHADOZ) Ozone Profiles (1998-2016). 2. Comparisons with satellites and ground-based instruments, J. Geophys. Res., 122, 13000-13025, https://doi.org/10.1002/2017JD027406, 2017.
Timmermans, R. M. A., van Oss, R. F., and Kelder, H. M.: Equatorial Kelvin wave signatures in ozone profile measurements from Global Ozone Monitoring Experiment (GOME), J. Geophys. Res., 110, D21103, https://doi.org/10.1029/2005JD005929, 2005.

Wargan, K., Orbe, C., Pawson, S., Ziemke, J. R., Oman, L. D., Olsen, M. A., Coy, L., and Knowland, K. E.: Recent decline in extratropical lower stratospheric ozone attributed to circulation changes, Geophys. Res. Lett., 45, 5166-5176, https://doi.org/10.1029/2018GL077406, 2018.

Witte, J. C., Thompson, A. M., Smit, H. G. J., Fujiwara, M., Posny, F., Coetzee, G. J. R., Northam, E. T., Johnson, B. J., Sterling, C. W., Mohammed, M., Ogino, S.-Y., Jordan, A., daSilva, F. R., and Zainal, Z.: First reprocessing of Southern Hemisphere Additional OZonesondes (SHADOZ) profile records (1998-2015) 1: Methodology and evaluation, J. Geophys. Res., 122, 6611-6636, https://doi.org/10.1002/2016JD026403, 2017.

Ziemke, J. R. and Stanford, J. L.: Quasi-biennial oscillation and tropical waves in total ozone, J. Geophys. Res., 99, 2304123056, 1994.

Ziemke, J. R., Chandra, S., Thompson, A., and McNamara, D.: Zonal asymmetries in Southern Hemisphere column ozone: Implications of biomass burning, J. Geophys. Res., 101, 1442114427, https://doi.org/10.1029/96JD01057, 1996.

Ziemke, J. R., Olsen, M. A., Witte, J. C., Douglass, A. R., Strahan, S. E., Wargan, K., Liu, X., Schoeberl, M. R., Yang, K., Kaplan, T. B., Pawson, S., Duncan, B. N., Newman, P. A., Bhartia, P. K., and Heney, M. K.: Assessment and applications of NASA ozone data products derived from Aura OMI/MLS satellite measurements in context of the GMI Chemical Transport Model, J. Geophys. Res.-Atmos., 119, 5671-5699, https://doi.org/10.1002/2013JD020914, 2014. 